\title{
Comparative cytogenetics among populations of Astyanax altiparanae (Characiformes, Characidae, Incertae sedis)
}

\author{
Maressa Ferreira Neto ${ }^{1}$, Marcelo Ricardo Vicari ${ }^{2}$, Edemar Furquim de Camargo ${ }^{2}$, Roberto Ferreira Artoni $^{2}$ \\ and Orlando Moreira-Filho ${ }^{1}$ \\ ${ }^{1}$ Laboratório de Citogenética, Departamento de Genética e Evolução, Universidade Federal de São Carlos, \\ São Carlos, SP, Brazil. \\ ${ }^{2}$ Departamento de Biologia Estrutural, Molecular e Genética, Universidade Estadual de Ponta Grossa, \\ Ponta Grossa, PR, Brazil.
}

\begin{abstract}
Cytogenetic data are presented for Astyanax altiparanae populations from three Brazilian hydrographic systems. The chromosomal data obtained in A. altiparanae support the hypothesis of diploid number conservation. However, small differences in the karyotype formula and number of nucleolar organizer regions were observed in these populations. The apparent karyotypical similarity among the studied populations strongly suggests a close relationship among them with some chromosomal divergences due to gene flow restriction.
\end{abstract}

Key words: cytotaxonomy, karyotype diversification, fish cytogenetics.

Received: October 7, 2008; Accepted: June 17, 2009.

Astyanax is a genus from the family Characidae widely distributed throughout South and Central America and previously assigned to the subfamily Tetragonopterinae (Géry, 1977). This group has been recently considered Incertae sedis for not exhibiting consistent evidence of monophyletism (Lima et al., 2003). Astyanax altiparanae is a typical species of the upper Paraná River Basin above Sete Quedas, Brazil (Garutti and Britski, 2000), with the exception of one population from a location in the Iguaçu River situated below this region (Graça and Pavanelli, 2002).

The cytogenetics of Neotropical fishes has greatly contributed to their systematics and taxonomy. There are numerous examples among Astyanax, mainly from the "scabripinnis" and "fasciatus" groups, in which the intraspecific cytogenetic variation among populations was shown to be much larger than that detected through morphological systematics, thereby forming true species complexes (Moreira-Filho and Bertollo, 1991; Artoni et al., 2006; Vicari et al., 2008a).

The aim of this work was to characterize the karyotypes of three A. altiparanae populations and to compare them with those described in the literature. This comparative analysis could reveal population markers and help to

Send correspondence to Marcelo Ricardo Vicari. Laboratório de Citogenética, Departamento de Biologia Estrutural, Molecular e Genética, Universidade Estadual de Ponta Grossa, Av. Carlos Cavalcanti 4748, 84030-900 Ponta Grossa, PR, Brazil. E-mail: vicarimr@pq.cnpq.br. establish cytosystematic, evolutionary and/or biogeographical relationships among the populations.

Forty-nine specimens of $A$. altiparanae were analyzed: nine specimens (five males and four females) from the Pântano Stream in the Tietê River Basin of the state of São Paulo; eight specimens (five males and three females) from the Feijão Stream in the Mogi-Guaçu River Basin in the state of São Paulo; and 32 specimens collected at the Salto Segredo hydroelectric power plant on the Jordão River in the Iguaçu River Basin in the state of Paraná. The procedures were approved by the Ethics Committee on Animal Experimentation of the Universidade Estadual de Ponta Grossa (Process no. 04741/08).

Chromosome preparations were obtained from anterior kidney cells using the in vivo colchicine treatment (Bertollo et al., 1978). Nucleolar organizer regions (NORs) were detected after silver nitrate staining (Ag-NOR) according to Howell and Black (1980) and C-banding was obtained as described in Sumner (1972).

Fluorescent in situ hybridization (FISH) was performed with a biotinyled $18 \mathrm{~S}$ rDNA probe from the fish Prochilodus argenteus (Hatanaka and Galetti Jr, 2004) and with a biotinyled 5S rDNA probe from the fish Leporinus elongatus (Martins and Galetti Jr, 1999). An Olympus BX50 epifluorescence microscope was used for the analysis.

Nearly 30 metaphases were analyzed per specimen to determine the diploid number, karyotype composition and Ag-NOR distribution. Chromosomes were classified as 
metacentric (m), submetacentric (sm), subtelocentric (st) and acrocentric (a) following Levan et al. (1964).

Fishes of the genus Astyanax have shown considerable karyotype diversity. The diploid and fundamental numbers ( $2 \mathrm{n}$ and $\mathrm{FN}$ ) allied to some other chromosome markers, allowed cytotaxonomic and evolutionary inferences regarding these fishes. The $A$. altiparanae popula- tions studied (Pântano Stream, Feijão Stream and Jordão River) have a diploid number of $2 \mathrm{n}=50$ chromosomes (Figure 1). However, differences in the fundamental numbers were found among the three populations analyzed. The specimens from the Pântano Stream displayed a $\mathrm{FN}=88$, with $6 m+28 s m+4 s t+12 a$. The Feijão Stream population had a $\mathrm{FN}=94$, with $6 \mathrm{~m}+30 \mathrm{sm}+8 \mathrm{st}+6 \mathrm{a}$, whereas the speci-
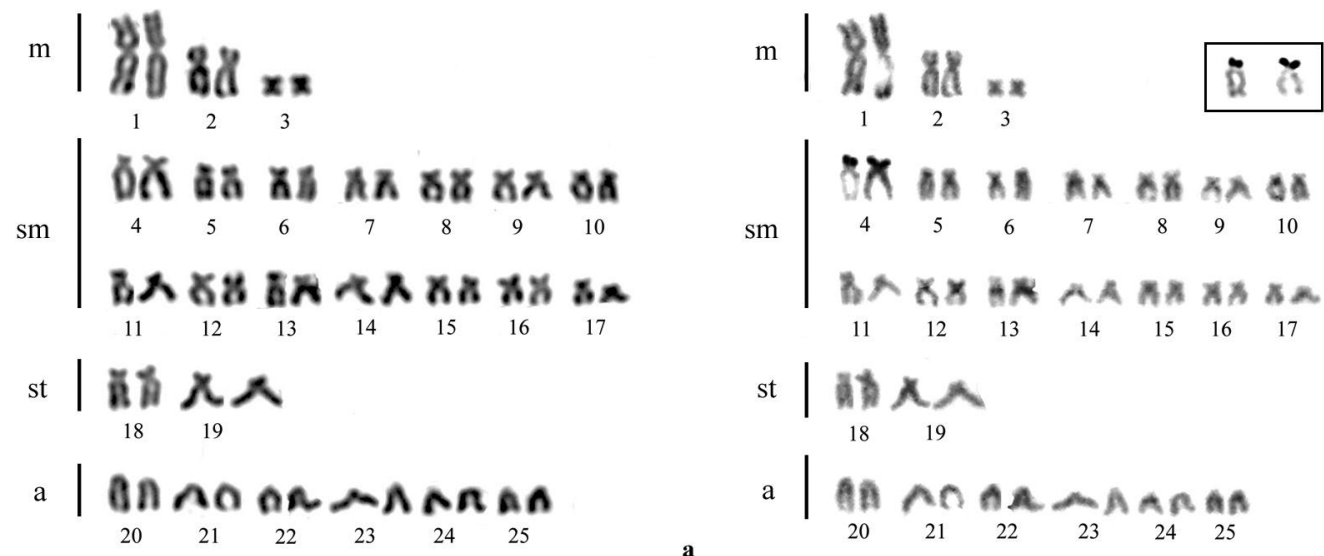

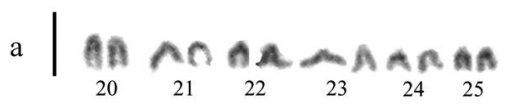
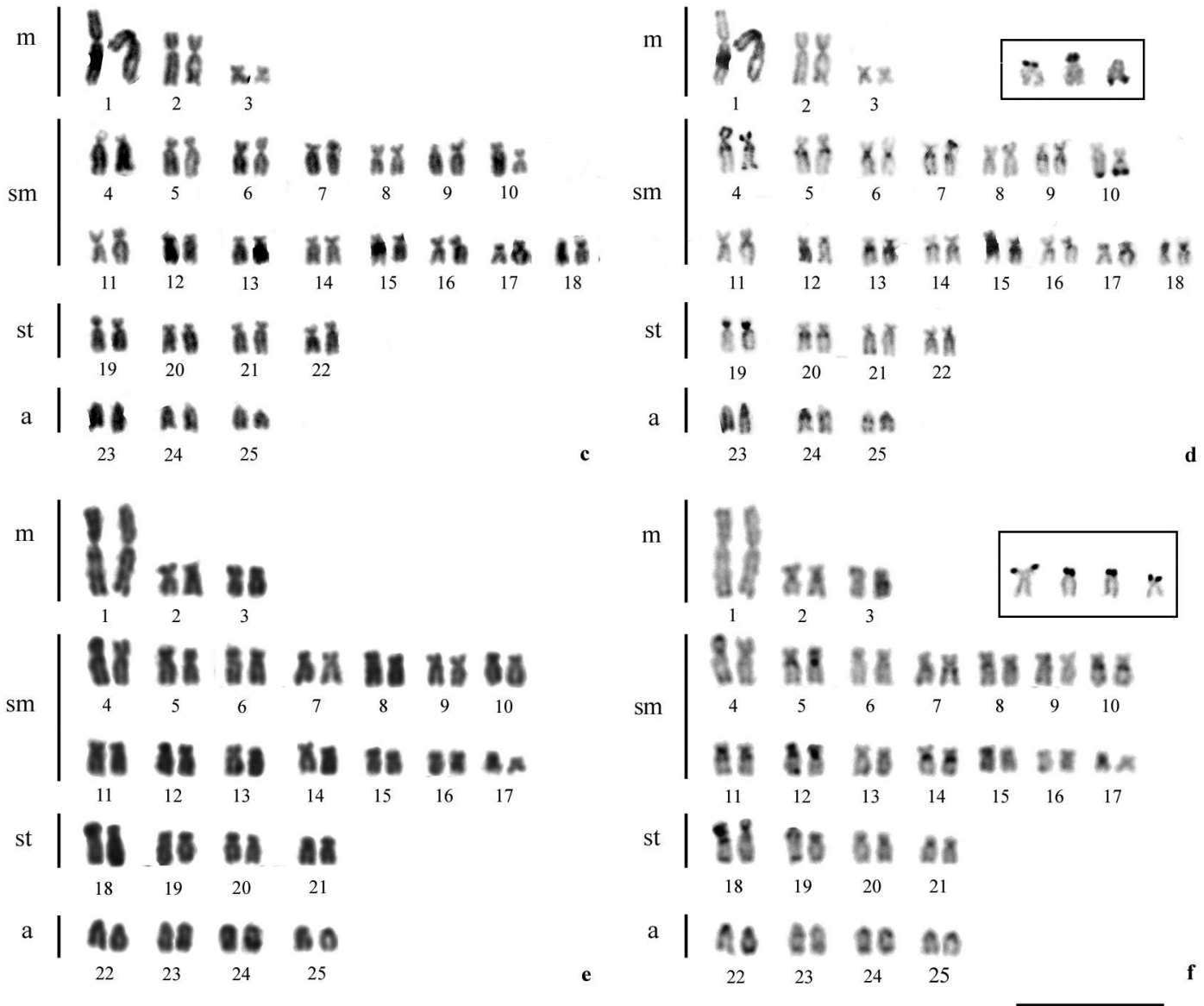

Figure 1 - Karyotypes of Astyanax altiparanae: population from the Pântano Stream after conventional Giemsa staining (a) and sequential C-banding (b); in the inset, the chromosomes with Ag-NORs. Population from the Feijão Stream after conventional Giemsa staining (c) and sequential C-banding (d); in the inset, the chromosomes with Ag-NORs. Population from the Jordão River after conventional Giemsa staining (e) and sequential C-banding (f); in the inset, the chromosomes with Ag-NORs. The bar represents $10 \mu \mathrm{m}$. 
mens from the Jordão River showed a $\mathrm{FN}=92$, with $6 \mathrm{~m}+28 \mathrm{sm}+8 \mathrm{st}+8 \mathrm{a}$ (Figure 1, Table 1). In the Jordão River population, chromosome pair 2 was smaller than the same pair in the Pântano and Feijão Streams populations (Figure 1). Variations in diploid number were observed between populations of species from the A. scabripinnis and A. fasciatus complexes and resulted from chromosome translocations (Mantovani et al., 2000; Artoni et al., 2006; Vicari et al., 2008a). Nevertheless, A. altiparanae exhibited a conserved $2 \mathrm{n}=50$ chromosomes in all the populations karyotyped (Table 1). Despite presenting the same 2n, different fundamental numbers were detected due to chromosome morphology variations. Non-Robertsonian rear- rangements, such as pericentric inversions were suggested to explain the karyotype differences among $A$. altiparanae populations (Domingues et al. 2007).

After C-banding, heterochromatic blocks were observed in the centromeric or pericentromeric regions of all chromosome pairs and in the telomeric regions of some chromosomes with small differences among the analyzed populations (Figure 1b, $d$ and $\mathrm{f}$ ). This results are similar to findings previously described for other A. altiparanae populations (Fernandes and Martins-Santos, 2004; Domingues et al., 2007). The small variations in constitutive heterochromatin distribution combined with the large variation in FN found among the A. altiparanae populations (Table 1)

Table 1 - Chromosome data from Brazilian populations of Astyanax altiparanae. Updated from Fernandes and Martins-Santos (2004).

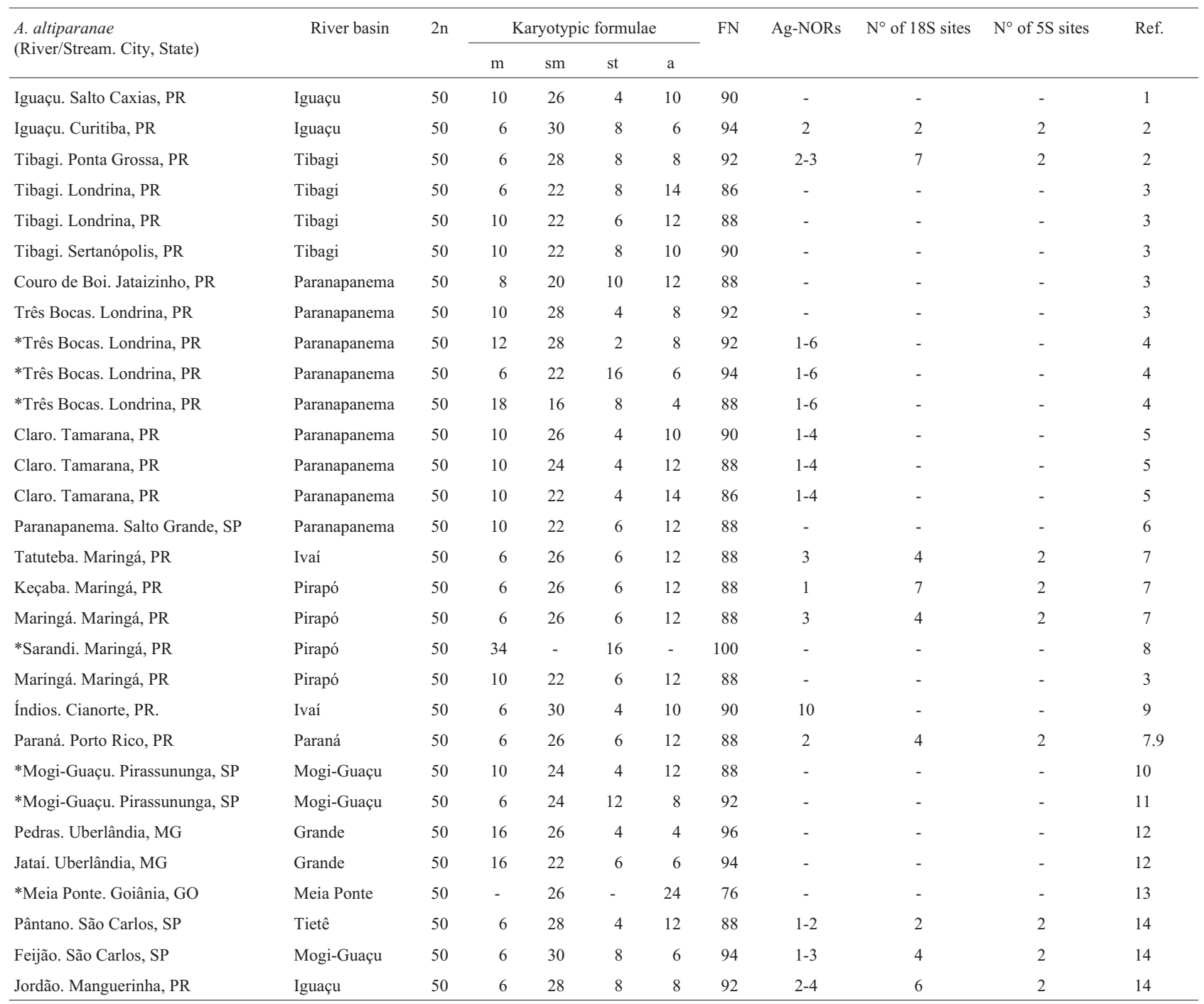

*Cited as Astyanax bimaculatus. $\mathrm{m}=$ metacentric; $\mathrm{sm}=$ submetacentric; $\mathrm{st}=$ subtelocentric; $\mathrm{a}=$ acrocentric; $\mathrm{FN}=$ fundamental number; PR = Paraná State; $\mathrm{SP}=$ São Paulo State; $\mathrm{MG}=$ Minas Gerais State; $\mathrm{GO}=$ Goiás State. Ref. = References : 1. Porto and Martins-Santos (2002 apud Fernandes and Martins-Santos, 2004); 2. Domingues et al. (2007); 3. Pacheco (2001 apud Fernandes and Martins-Santos, 2004); 4. Takahashi (1995 apud Fernandes and Martins-Santos, 2004); 5. Pacheco et al. (2001); 6. Daniel-Silva and Almeida-Toledo (2001); 7. Fernandes and Martins-Santos (2006); 8. Vale and Martins-Santos (1998 apud Fernandes and Martins-Santos, 2004); 9. Fernandes and Martins-Santos (2004); 10. Morelli et al. (1983); 11. Paganelli (1990 apud Fernandes and Martins-Santos, 2004); 12. Barbosa et al. (2002 apud Fernandes and Martins-Santos, 2004); 13. Jim and Toledo (1975 apud Fernandes and Martins-Santos, 2004). 14. Present study. 
supports the hypothesis that this structural variation is not due to the amplification of heterochromatic sequences. Thus, the different FNs observed in A. altiparanae populations, sometimes even within the same hydrographic basin, such as the Tibagi, Paranapanema and Mogi-Guaçu Rivers, must be mainly due to pericentric inversions.

Silver-nitrate staining (Ag-NORs) and FISH with the 18S rDNA probe evidenced a single NOR-bearing pair in the population of the Pântano Stream, while the populations of the Feijão Stream and the Jordão River exhibited multiple terminal signals on different chromosomes (Figure 1, in the insets; and Figure 2a, c and e). Chromosome rearrangements and transference of ribosomal sites could cause these variations, but transposition events have been suggested as the main mechanism to explain the majority of cases of NORs variability in the genome of these animals (Mantovani et al., 2000; Vicari et al., 2008b). Together with variations in the fundamental number, Ag-NORs are important cytogenetic markers to determine differences among populations in this species (Pacheco et al., 2001; Fernandes and Martins-Santos, 2004; 2006). Domingues et al. (2007) car-

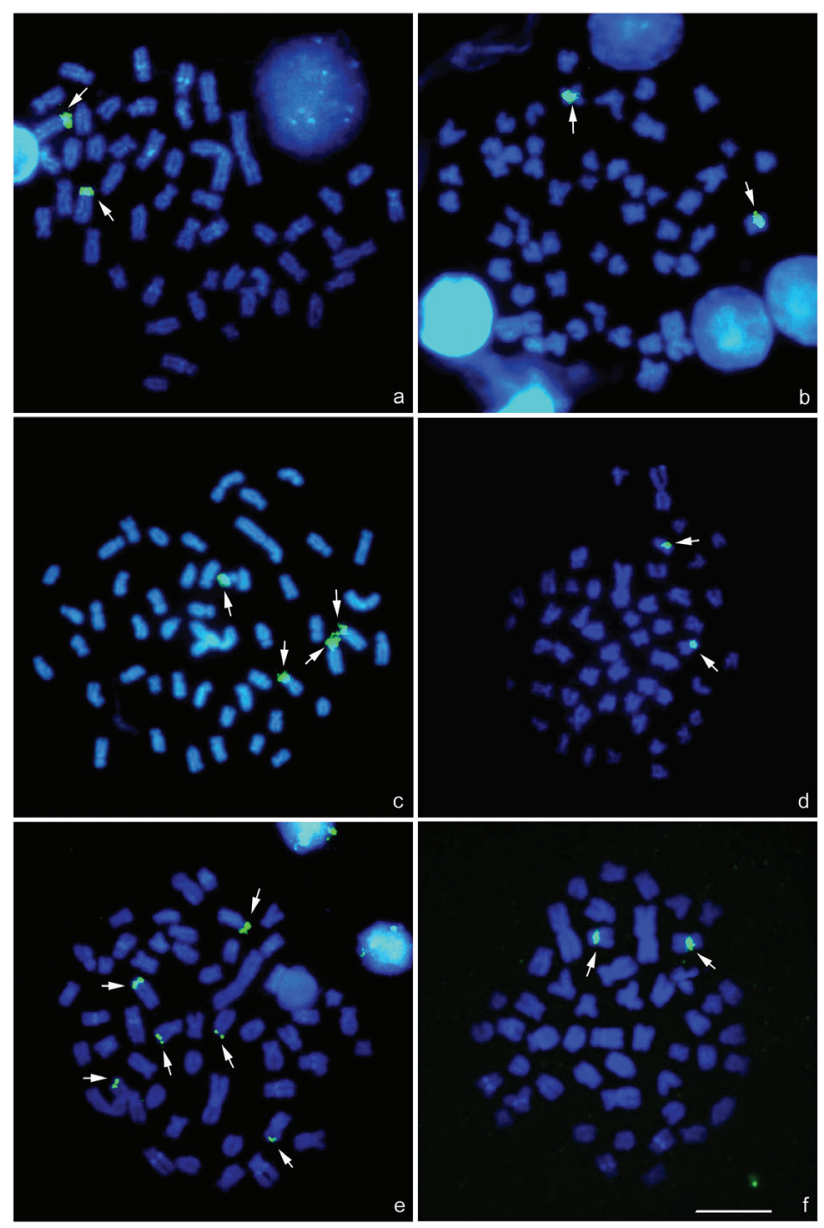

Figure 2 - Chromosome spreads of Astyanax altiparanae after FISH: (a) $18 \mathrm{~S}$ and (b) $5 \mathrm{~S}$ rDNA sites in the population from the Pântano Stream (c) $18 \mathrm{~S}$ and (d) $5 \mathrm{~S}$ rDNA sites in the Feijão Stream population; and (e) $18 \mathrm{~S}$ and (f) $5 \mathrm{~S}$ rDNA sites in the Jordão River population. The bar represents $10 \mu \mathrm{m}$. ried out a comparative cytogenetic and morphometric study on A. altiparanae populations from the upper Tibagi and Iguaçu Rivers. These authors found a similar karyotype macrostructure in the populations with differences in the number of major rDNA sites between populations. The Ag-NORs and 18S rDNA FISH data (Table 1) also revealed variations between populations of this species both within the same and from different hydrographic basins.

While variations in the number of $18 \mathrm{~S}$ rDNA sites occurred between populations of $A$. altiparanae, only one signal in the proximal long arm of a sm chromosome was observed after FISH with the 5S rDNA probe (Figure 2b, d and e) (Fernandes and Martins-Santos, 2004; 2006; Domingues et al., 2007; Peres et al., 2008; present study). The $5 \mathrm{~S}$ rDNA sites seemed to be conserved in the proximal region of the long arm of two chromosome pairs (one $\mathrm{m}$ and one a) in populations of the A. scabripinnis complex (Ferro et al., 2001; Almeida-Toledo et al., 2002; Mantovani et al., 2005; Vicari et al., 2008a). In Astyanax sp. D and in $A$. janeiroensis, the $5 \mathrm{~S}$ rDNA site was located in the proximal region of the long arm of a single acrocentric pair, similar to what was found in the A. scabripinnis complex (Kantek et al., 2007; Vicari et al., 2008b, respectively). Mantovani et al. (2000) proposed that 5S rDNA sites in the proximal position of the long arm indicated a conserved pattern for these genes in Astyanax. Thus, the chromosomes with $5 \mathrm{~S}$ rDNA sites would be the same among the A. altiparanae populations studied, but would diverge in morphology and number of $5 \mathrm{~S}$ rDNA sites in other populations of the genus.

The cytogenetic data from the three $A$. altiparanae populations studied herein are similar to those from other populations of this species reported in the literature. This observation strengthens the hypothesis of a conserved $2 n=50$. Nevertheless, differences in the karyotypic formula and in the number of nucleolar organizer regions were noticed when comparing the data from these populations to those already described for other populations. The apparent karyotype similarity strongly suggests a close relationship among the studied populations, but the small karyotypic differences detected indicate some evolutionary divergence due to gene flow restrictions.

\section{Acknowledgments}

The authors are grateful to the IAP (Instituto Ambiental do Paraná) and IBAMA (Instituto Brasileiro do Meio Ambiente) for authorizing the capture of specimens (IBAMA/MMA/SISBIO license number: 15117). This work was supported by CNPq (Conselho Nacional de Desenvolvimento Científico e Tecnológico Processo: 473448/2007-6), CAPES (Coordenação de Aperfeiçoamento de Pessoal de Nível Superior) and Fundação Araucária (Fundação Araucária de Apoio ao Desenvolvimento Científico e Tecnológico do Estado do Paraná, Processo: 12938). We also thank Mr. Miguel Airton Carvalho for his collaboration in the field work and in the laboratory. 


\section{References}

Almeida-Toledo LF, Ozouf-Costaz C, Foresti F, Bonillo C, Porto-Foresti F and Daniel-Silva MFZ (2002) Conservation of the 5S-bearing chromosome pair and co-localization with major rDNA clusters in five species of Astyanax (Pisces, Characidae). Cytogenet Genome Res 97:229-233.

Artoni RF, Shibatta OA, Gross MC, Schneider CH, Almeida MC, Vicari MR and Bertollo LAC (2006) Astyanax aff. fasciatus Cuvier, 1819 (Teleostei; Characidae): Evidences of a species complex in the upper rio Tibagi basin (Paraná, Brazil). Neotrop Ichthyol 4:197-202.

Bertollo LAC, Takahash CS and Moreira-Filho O (1978) Cytotaxonomic considerations on Hoplias lacerdae (Pisces, Erythrinidae). Braz J Genet 1:103-120.

Daniel-Silva MFZ and Almeida-Toledo LF (2001) Chromosome R-banding pattern and conservation of a marker chromosome in four species, genus Astyanax (Characidae, Tetragonopterinae). Caryologia 54:209-215.

Domingues MS, Vicari MR, Abilhoa V, Wamser JP, Cestari MM, Bertollo LAC, Almeida MC and Artoni RF (2007) Cytogenetic and comparative morphology of two allopatric populations of Astyanax altiparanae Garutti \& Britski, 2000 (Teleostei, Characidae) from upper rio Paraná basin. Neotrop Ichthyol 5:37-44.

Fernandes CA and Martins-Santos IC (2004) Cytogenetic studies in two populations of the Astyanax altiparanae (Pisces, Characiformes). Hereditas 141:328-332.

Fernandes CA and Martins-Santos IC (2006) Mapping of the 18S and 5S ribosomal RNA genes in Astyanax altiparanae Garutti \& Britski, 2000 (Teleostei, Characidae) from the upper Paraná river basin, Brazil. Genet Mol Biol 29:464-468.

Ferro DAM, Moreira-Filho O and Bertollo LAC (2001) Nucleolar organizing regions, $18 \mathrm{~S}$ and $5 \mathrm{~S}$ in Astyanax scabripinnis (Pisces, Characidae): Populations distribution and functional diversity. Genetica 110:55-62.

Garutti V and Britski HA (2000) Descrição de uma nova espécie de Astyanax (Telostei, Characidae) da bacia do Alto Paraná e considerações sobre as demais espécies do gênero na bacia. Comun Mus Ciênc Ser Zool PUCRS 13:65-88.

Géry J (1977) Characoids of the World. TFH Publications, Neptune, $672 \mathrm{pp}$.

Graça WJ and Pavanelli CS (2002) Astyanax altiparanae Garutti \& Britski, 2000 (Osteichthyes, Characidae) in the Iguaçu River basin. Acta Scient 24:451-453.

Hatanaka T and Galetti Jr PM (2004). Mapping of the 18S and 5S ribosomal RNA genes in the fish Prochilodus argenteus Agassiz, 1829 (Characiformes, Prochilodontidae). Genetica 122:239-244.

Howell WM and Black DA (1980) Controlled silver staining of nucleolus organizer regions with a protective colloidal developer: A 1-step method. Experientia 36:1014-1015.

Kantek DLZ, Noleto RB, Fenocchio AS and Cestari MM (2007) Cytotaxonomy, heterochromatic polymorphism and natural triploidy of a species of Astyanax (Pisces, Characidae) endemic to the Iguaçu River Basin. Braz Arch Biol Technol 50:67-74.

Levan A, Fredga K and Sandberg AA (1964) Nomenclature for centromeric position on chromosomes. Hereditas 52:201220.

Lima FCT, Malabarba LR, Buckup PA, Silva JFP, Vari RP, Harold A, Benine R, Oyakawa OT, Pavanelli CS, Menezes NA, et al. (2003) Genera Incertae Sedis in Characidae. In: Reis RE, Kullander SVENO and Ferraris Jr. CJ (eds) Check list of the freshwater fishes of South and Central America. $1^{\text {st }}$ edition. Edipucrs, Porto Alegre, pp 106-169.

Mantovani M, Abel LDS, Mestriner CA and Moreira-Filho O (2000) Accentuated polymorphism of heterochromatin and nucleolar organizer regions in Astyanax scabripinnis (Pisces, Characidae): Tools for understanding karyotypic evolution. Genetica 109:161-168.

Mantovani M, Abel LDS and Moreira-Filho O (2005) Conserved $5 \mathrm{~S}$ and variable $45 \mathrm{~S}$ rDNA chromosomal localization revealed by FISH in Astyanax scabripinnis (Pisces, Characidae). Genetica 123:211-216.

Martins C and Galetti Jr PM (1999) Chromosomal localization of 5S rDNA genes in Leporinus fish (Anostomidae, Characiformes). Chromosome Res 7:363-367.

Moreira-Filho O and Bertollo LAC (1991) Astyanax scabripinnis (Pisces, Characidae): A species complex. Braz J Genet 14:331-357.

Morelli S, Bertollo LAC, Foresti F, Moreira-Filho O and Toledo-Filho SA (1983) Cytogenetic considerations on the genus Astyanax (Pisces, Characidae). I. Karyotypic variability. Caryologia 36:235-244.

Pacheco RB, Giuliano-Caetano L and Dias AL (2001) Cytotypes and multiple NORs in an Astyanax altiparanae population (Pisces, Tetragonopterinae). Chromosome Sci 5:109-114.

Peres WAM, Bertollo LAC and Moreira-Filho O (2008) Physical mapping of the $18 \mathrm{~S}$ and $5 \mathrm{~S}$ ribosomal genes in nine Characidae species (Teleostei, Characiformes). Genet Mol Biol 31:222-226.

Sumner AT (1972) A simple technique for demonstrating centromeric heterochromatin. Exp Cell Res 75:304-306.

Vicari MR, Noleto RB, Artoni RF, Moreira-Filho O and Bertollo LAC (2008a) Comparative cytogenetics among species of the Astyanax scabripinnis complex. Evolutionary and biogeographical inferences. Genet Mol Biol 31:173-179.

Vicari MR, Artoni RF, Moreira-Filho O and Bertollo LAC (2008b) Co-localization of repetitive DNAs and silencing of major rDNA genes. A case report in the fish, Astyanax janeiroensis. Cytogenet Genome Res 122:67-72.

Associate Editor: Fausto Foresti

License information: This is an open-access article distributed under the terms of the Creative Commons Attribution License, which permits unrestricted use, distribution, and reproduction in any medium, provided the original work is properly cited. 